Miami Nature Biotechnology Short Reports

TheScientificWorld (2001) 1(S3), 107SR

ISSN 1532-2246; DOI 10.1100/TSW.2001.124

\title{
STIMULATION OF APOPTOSIS BY COMPUTATIONALLY DERIVED SMALL MOLECULES THAT BIND TO BCL-2
}

Martha Mutomba*, Jing Wang, Sergei Mailiartchouk, Tom Brady, Darryl Rideout, Christina Niemeyer, Hengyi Zhu, Cindy Fisher, Seymour Mong, and Kal Ramnarayan

Structural Bioinformatics Inc., 10929 Technology Place, San Diego, CA 92127, USA

*mutomba@strubix.com

INTRODUCTION. Bcl-2 and its family members are key regulators of apoptosis or programmed cell death, implicated in human diseases including cancer (1). The family has both anti-apoptotic members such as Bcl-2 and Bcl- $\mathrm{x}_{\mathrm{L}}$ and also death-promoting members such as Bax, Bak, Bid and Bad $(1,2)$. The interactions between these two groups of proteins have been shown to modulate the sensitivity of a cell to apoptotic stimuli $(3,4)$. Most cancers typically show high levels of Bcl-2 expression, and this overexpression is believed to contribute to the resistance of cancers to a wide variety of chemotherapeutic drugs and radiation therapy (5). In our studies, we used structure-based computer screening technology to identify small molecule Bcl-2 antagonists. These compounds were assayed for binding to Bcl-2 and then in cell-based functional assays. Positive compounds can potentially be developed as anti-cancer therapies.

METHODS. The NMR structure of Bcl- $\mathrm{x}_{\mathrm{L}}$ complexed with a portion of the BH3 region of its ligand Bak (PDB accession number 1BXL) (6) was used to generate a computational model of Bcl-2 complexed with a corresponding portion of its intracellular ligand Bax. The model was used in a 3-D computational search for non-peptide small molecules that disrupt Bcl-2/Bax interaction. Selected compounds were tested for their ability to inhibit binding of $\mathrm{Eu}^{3+}$-labelled Bax to Bcl-2 as measured by time-resolved fluorometry. Compounds with Ki values less than $50 \mu \mathrm{M}$ were tested for their ability to induce apoptosis in Jurkat cells that overexpress Bcl-2 (Jurkat/Bcl-2 cells). The published Bcl-2 binding compound HA14-1 (7), was used as a control in the biochemical and cellular assays.

RESULTS. Two compounds with Ki values of $6 \mu \mathrm{M}$ and $25 \mu \mathrm{M}$ in the binding assay showed anti-Bcl-2 activities in cell-based assays. Jurkat/Bcl-2 cells are resistant to apoptosis induced by $1 \mu \mathrm{M}$ staurosporine, as measured by cleavage of caspase 3 and PARP. However, caspase 3 and PARP cleavage were observed when these cells were incubated with $1 \mu \mathrm{M}$ staurosporine in addition to either of these two compounds at 30 and $100 \mu \mathrm{M}$. Furthermore, the compounds induced apoptosis in a breast cancer cell line, MCF-7, which overexpresses Bcl-2.

CONCLUSION. Two chemically distinct compounds were identified as Bcl-2 antagonists, leading to induction of apoptosis in Bcl-2 overexpressing cells. These results suggest that targeting Bcl-2 may lead to the development of new anti-cancer agents.

ACKNOWLEDGEMENTS. This work was supported in part by a grant from NIH. 


\section{REFERENCES.}

1. $\quad$ Chao, D. and Korsmeyer, S.J. (1998) Annu. Rev. Immunol. 16, 395-419

2. $\quad$ Adams, J. and Cory, S. (1998) Science 281, 1322-1326

3. Yin, X.-M., Oltvai, Z. N., and Korsmeyer, S.J. (1994) Nature 369, 321-323

4. $\quad$ Oltvai, Z.N. and Korsmeyer, S.J. (1994) Cell 79, 189-192

5. $\quad$ Reed, J.C. (1999) Curr. Opin. Oncol. 1, 68-75

6. Sattler, M., Liang, H., Nettsheim, D., Meadows, R.P., Harlan, J.E., Eberstadt, M., Yoon, H.S., Shuker, S.B., Chang, B.S., Minn, A.J., et al. (1997) Science 275, 983-986

7. $\quad$ Wang, J.-L., Liu, D., Zhang, Z.-J., Shan, S., Han, X., Srinivasula, M., Croce, C.M., Alnemri, E.S., and Huang, Z. (2000) Proc. Natl. Acad. Sci. U S A 97, 7124-7129 

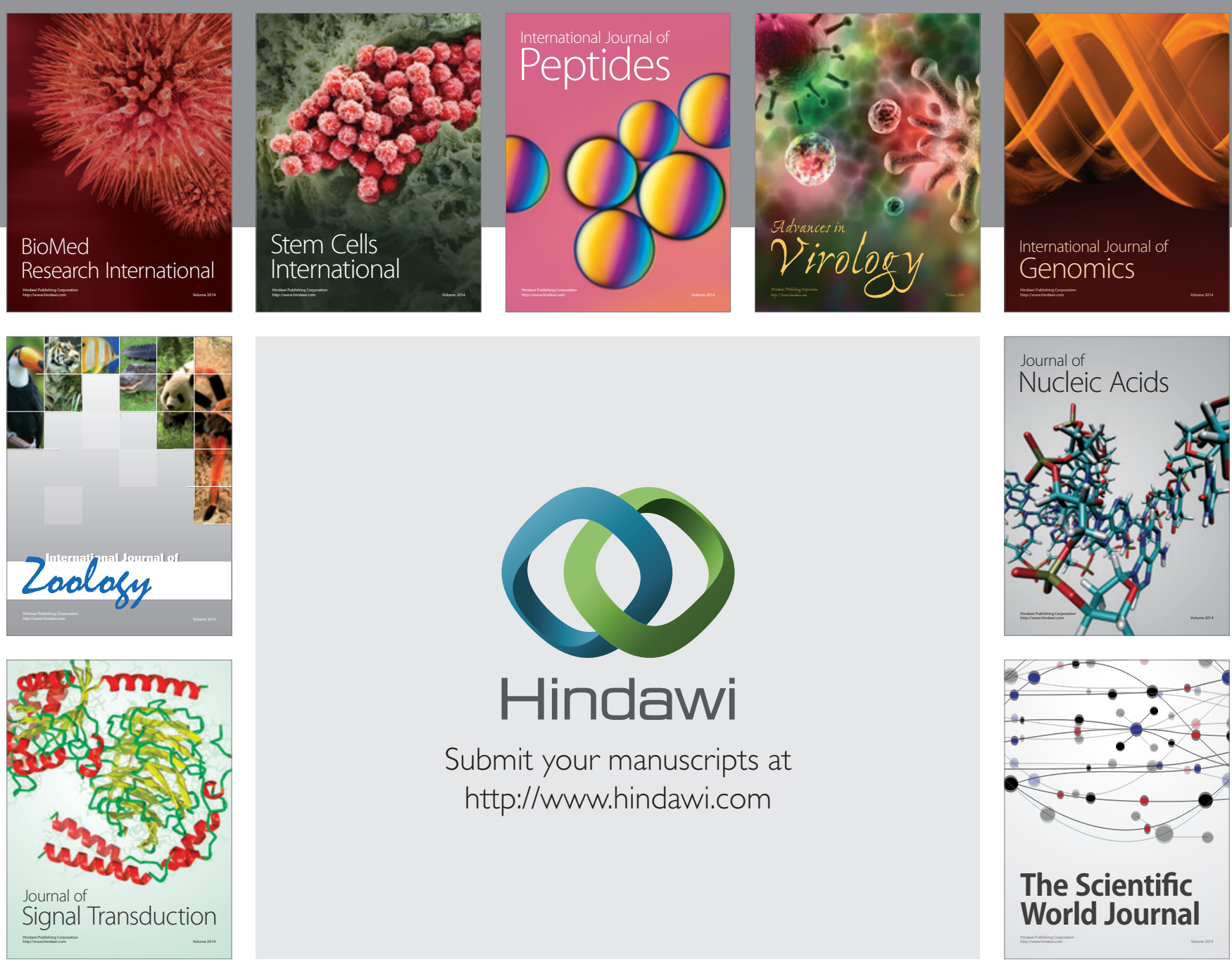

Submit your manuscripts at

http://www.hindawi.com
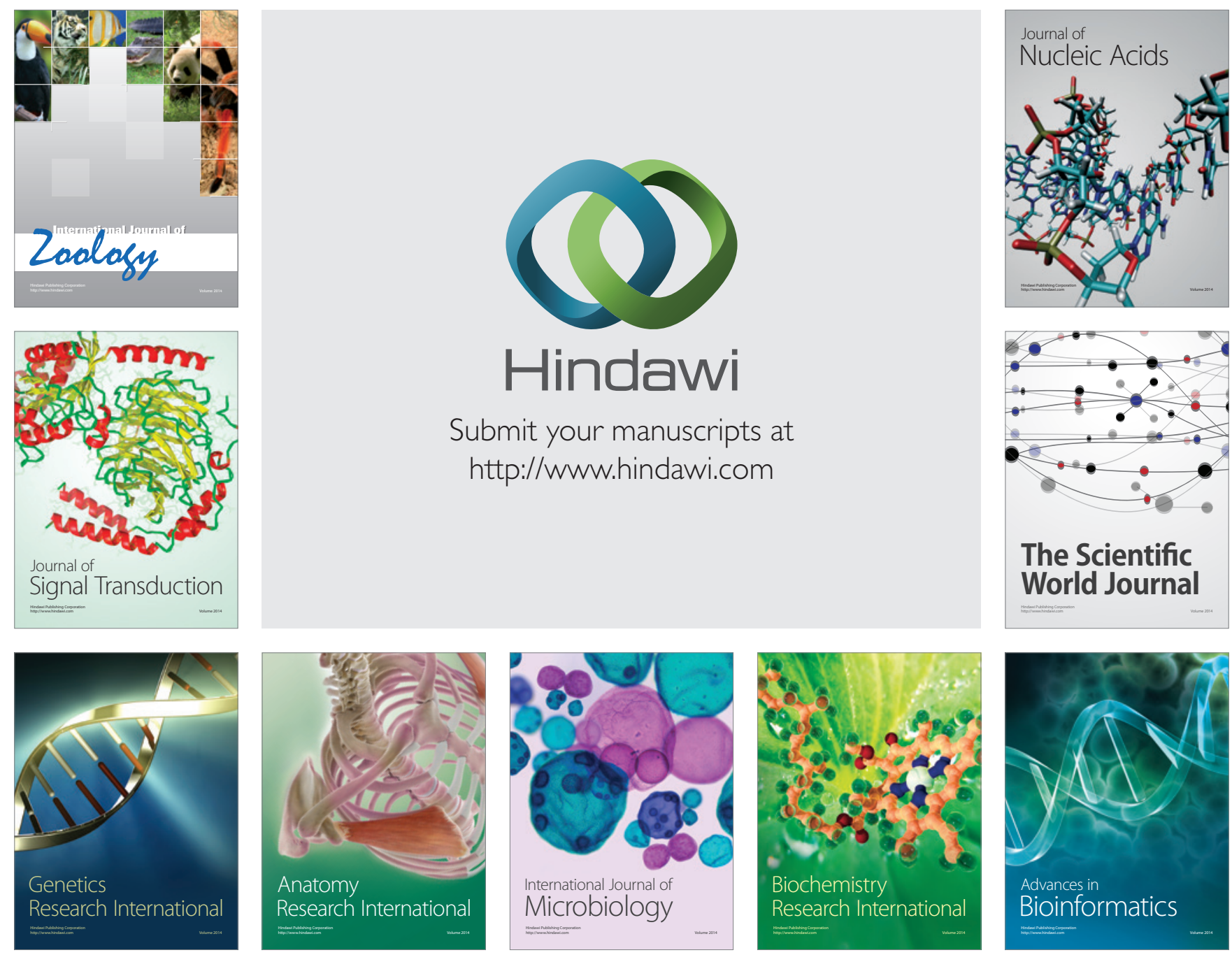

The Scientific World Journal
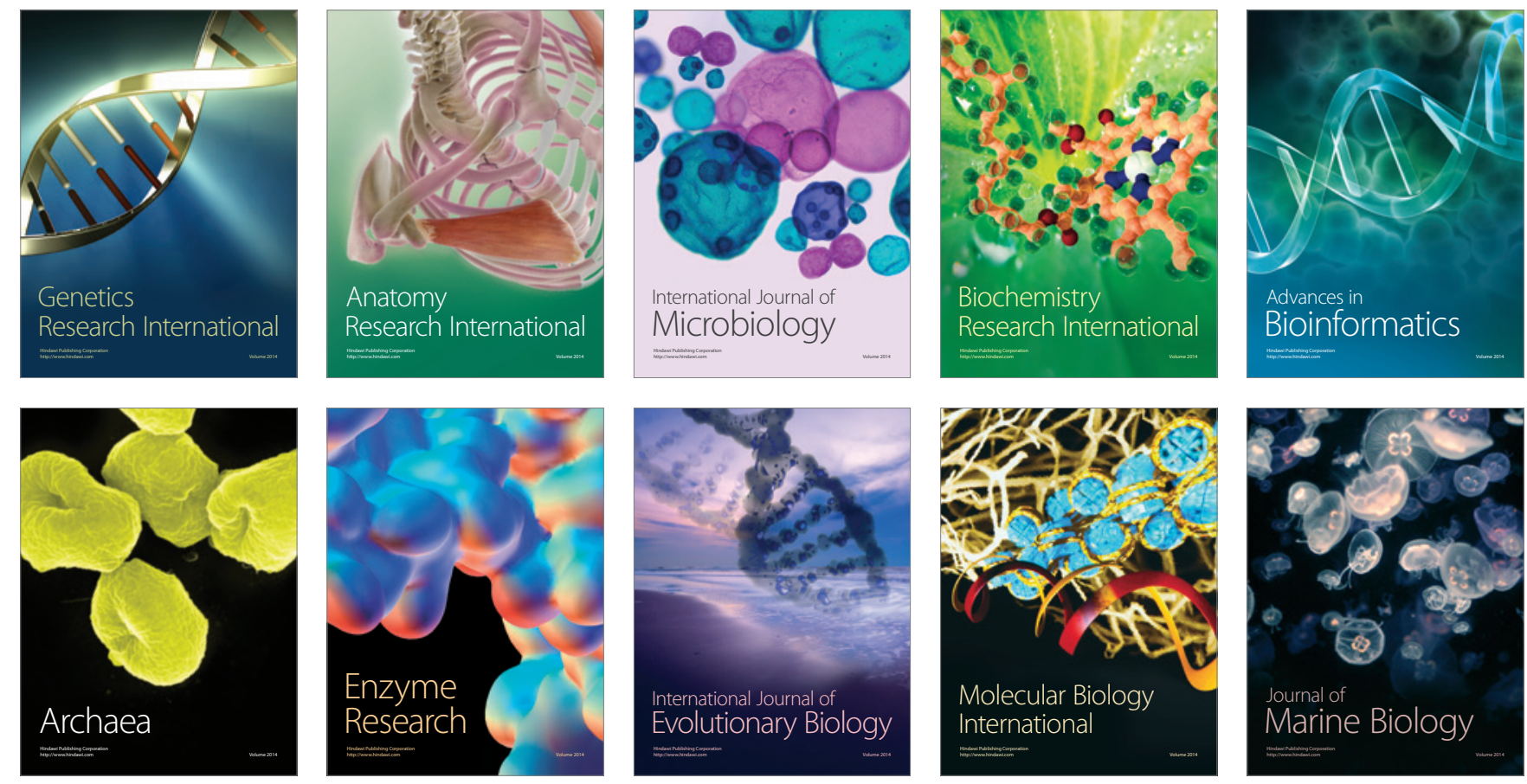